\title{
非対称および不均一熱放射環境の人体影響表現方法の研究 INDICATION OF ASYMMETRIC AND UNEVEN THERMAL RADIATION ENVIRONMENT RELATED TO THERMAL COMFORT AND DISCOMFORT
}

\author{
堀越 哲 美*, 土川忠 浩**, 蔵 澄 美 仁***, 平山慶太郎****, 小林陽太郎***** \\ Tetsumi HORIKOSHI, Tadahiro TSUCHIKAWA, Yoshihito KURAZUMI, \\ Keitaro HIRAYAMA and Yôtaro KOBAYASHI
}

\begin{abstract}
This paper aims to introduce the indices on the effect of asymmetric and uneven thermal radiation upon the human body. Partial mean radiant temperature and partial operative temperature were defined on each plane of the rectangular solid as a model of the human body. Standard deviation of the partial mean rediant temperatures was applied to the indication of asymmetry and unevenness of the radiation field. This quantity was named thermal radiation unevenness. Experiments were carried out to verify these indices. Local skin temperature and local thermal sensation vote corresponded to the partial mean radiant temperature and partial operative temperature. The thermal radiation asymmetry and unevenness can express the unevenness of the partial mean radiant temperature on each plane of the rectangular-solid.
\end{abstract}

Keywords: thermal radiation, asymmetry, thermal comfort, partial mean radiant temperature, skin temperature, rectangular solid

1.はじめに

現実の居住空間においては，室内では葖や家具があり 部位によって仕上げ材も異なりその表面温度は必ずしも 均一ではない。特に窓面は日射の入射や冬季の夜間の冷 放射など不均一環境が生まれやすい。一方、放射暖房は 室内均等に施されることはなく，非対称な放射熱源とな ることがある。都市空間においては日射をはじめ熱放射 環境は全く不均一な状態にある。このように，ほとんど の場合，人間は非対称あるいは不均一な熱放射環境に曝 されているといえよう。著者ら”は，すでに㝕面からの 冷放射や放射暖房の不均一性について考慮することが必 要であることを述べた。中村 ${ }^{21}$ は熱放射環境はその方向 性を考虑する必要のあることを強調した。このように， 熱環境の設計や熱放射環境の評価に際しては, 人体に対 し非対称性をもつ熱放射源のある場合や不均一な熱放射 環境の人体に及ぼす影響を的確に表現する方法が必要で ある。

早い時期に，熱放射環境の非対称性について研究を 行ったのはVernon ${ }^{3 !}$ であり,グローブ温度計の開発の
中で, グローブ温度計の表面温度の分布と人体着衣表面 温度などとの対応について実験を行った。これは局所に おける一種の作用温度の計測であったと考えられる。そ れ以後の研究の流れの中で, 人体の局所に対する熱放射 や指向性のある熱放射は, 微小面に対して定義された平 均放射温度を以て表現されてきた。これは，指向性平均 放射温度 (Korsgaard $\left.{ }^{4)}\right)$, 面放射温度 $\left(\right.$ Emmerson $^{5)}$ ), 放射束ベクトル $\left(\right.$ 中村 $\left.^{2)}\right)$, ベクトル放射温度 $\left(\mathrm{McIntyr}^{6)}\right)$ や指向性作用温度 (Mundt ${ }^{7)}$ ) として利用されてきた。 中村 ${ }^{2}{ }^{\prime}$ は理解の容易さと平均放射温度との関係から, 放 射束ベクトルをベクトル放射温度で表現し，微小立方体 の各面に重みをつけた形態係数を採用して評価を行うこ とを提案した。Boeke と Wall ${ }^{8)}$ は中村 ${ }^{21}$ と同様の微小立 方体を“6うのセンサー要素” six small sensing elements からなる“微小立方体センサー” sensing cube と して室内での熱放射の不均一性を表現することを提案し た。微小立方体各面における平均放射温度を定義し, 全 体平均放射温度を 6 面の平均放射温度の平均值で表すこ とを示した。さらに，熱放射の非対称性を背中合わせの

\footnotetext{
本論文は, 日本建築学会大会および日本生気象学会総会で口頭発表した内容を取りまとめ, 訂正加筆したものである。

$*$ 名古屋工業大学 助教授・工博

** 岐皁工業高等専門学校 助手・工修

****東ソ一 (株) ・ 工修

**** 旭化成工業 $($ 株.) $\cdot$ 工修

****** 豊橋技術科学大学 名誉教授・工博

Associate Prof. of Nagoya Institute of Technology, Dr. Eng.

Research Assistant of Gifu National College of Technology, M. Eng. Tohso Corp.

Asahi Chemical Industry

Emeritus Prof. of Toyohashi Univ. of Technology, Dr. Eng.
} 
微小面の平均放射温度差を全体の平均放射温度で除した “放射の非対称性” Radiative Asymmetryによって放 射環境を表現することを提案した。Fanger ら”は，背 中合わせの微小面平均放射温度の差を “放射非対称性” Radiation Asymmetry と称し, 非対称性の表現として 用いられている。これらの表現方法はすべて微小面また は微小立体を人体中心に置いて, 非対称性や指向性につ いての表現として用いている。しかし，実際人体各部位 に入射する熱放射は分布があり，人体中心での表現に よって代表されるとは限らない。したがって，これらの 表現は空間の点における表現法と考えることが妥当であ ろう。中村 ${ }^{2)}$ 場合は重み係数の導入によってより人体 へ近付かせる考慮がなされている。BoekeとWall' 非対称性の表現では, 微小面平均放射温度差を平均放射 温度を間隔尺度である ${ }^{\circ} \mathrm{C}$ で表現した值で除する点に問 題がある。McIntyre ${ }^{6)} と F$ anger $ら^{97}$ の表現は本質的に Korsgaard ${ }^{4)}$ の方法と等しい。

そこで，本研究では人体を大きさのある直方体（また は立方体) としてモデル化し, 直方体全体 - 各構成面 · 局所の微小面での平均放射温度・作用温度を定義し, そ れを用いて非対称・不均一な熱放射環境の人体影響を表 現する方法を開発しようとするものである。この表現方 法の妥当性検証のため, 被験者を用いた実験を行った。

\section{2. 非対称・不均一熱放射環境の表現の定式化}

\section{1 部分平均放射温度}

人体表面に入射する熱放射の分布や人体各部位ごとの 平均放射温度を求めることは煩雑であり，特に連続的な 分布は求めることが極めて困難である。そこで, 人体を, 前後·左右・上下の 6 方向の指向性を持ち，入射する放 射の分布も考慮できる, 単純な立体である直方体に置き 換えて, 表現することとした。人体各部はそれぞれ, 直 方体の各面に相当する方向を向いていると考え, 直方体 に集約されるとした。立位人体は直方体 $(0.4 \mathrm{~m} \times 0.2$ $\mathrm{m} \times 1.2 \mathrm{~m}$ ) に, 椅座位人体は立方体 (各辺 $0.5 \mathrm{~m})$ に 相当するとして, 各立体と矩形面との間の形態係数およ び各立体上の各面と矩形面との間の形態係数 (Horikoshi と Kobayashi ${ }^{1), 10)}$ ) がすでに求められている。本研究で も，人体モデルとしてこの直方体・立方体を用いる。こ の形態係数を用いれば，直方体の各面における平均放射 温度および直方体全体に対する平均放射温度が求められ る。本研究で, 人体モデルとしての立方体各構成面に対 応させた人体部位とその略号を図一1に示す。

直方体の一面 $j$ 上の微小面 $d j$ における平均放射温度 $M R T_{d j}\left[{ }^{\circ} \mathrm{C}\right]$ は, 次のように定義される。ここでは矩 形面で構成される空間を考え, その表面は完全拡散面で 完全黒体とし, 放射熱授受は直射のみを考える。直方体 の一面 $j$ 上の微小面 $d j$ 亡矩形面 $i$ との直接放射熱交換

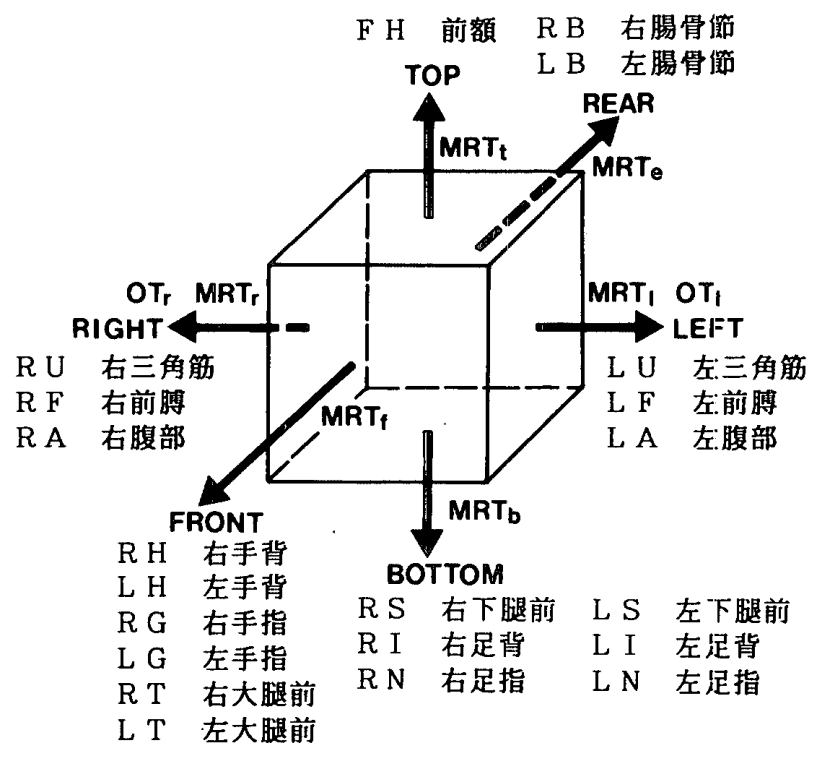

图一1人体モデルとしての立方体各面に対応する平均放射温 度・作用温度と人体皮咸温測定部位とその略号

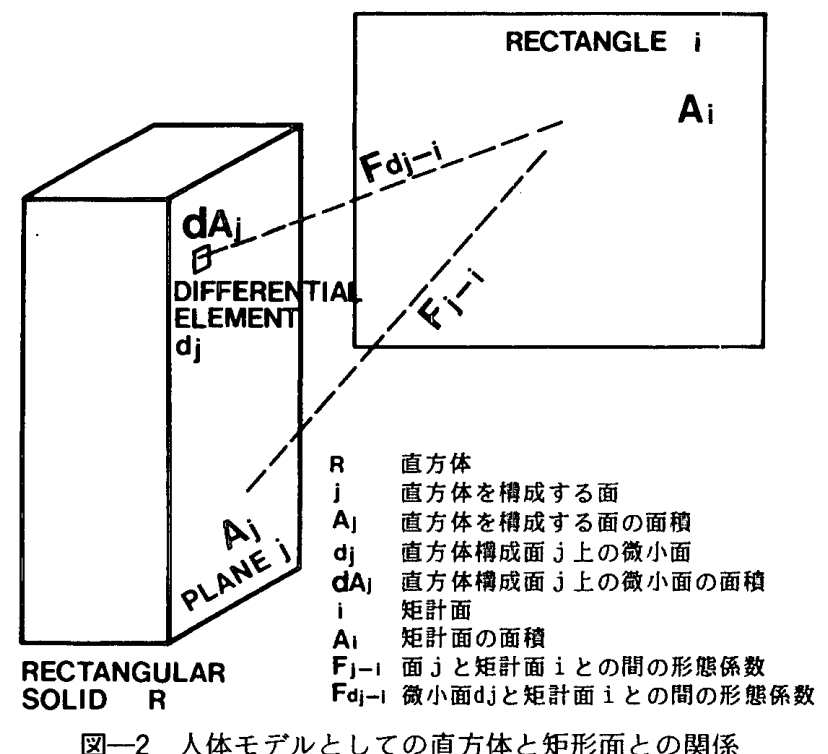

图一2 人体モデルとしての直方体と矩形面との関係

\begin{tabular}{|c|c|c|c|}
\hline & & & \\
\hline A & : 面䖽 & {$\left[\mathrm{m}^{2}\right]$} & 添字 \\
\hline $\mathrm{b}$ & :無次元式のべき数 & {$[-]$} & $\mathrm{j}$ ：直方体を㩐成する面 \\
\hline $\mathrm{C}$ & :無次元式の定数 & {$[-$ ] } & $\mathrm{d} \mathrm{j}$ ：直方体を輩成する面 $\mathrm{j}$ 上の微小面 \\
\hline $\mathrm{dA}$ & : 微小面の面䅡 & {$\left[\mathrm{m}^{2}\right]$} & $\mathrm{R}$ ：直方体 \\
\hline $\mathrm{F}$ & : 形照係数 & {$[-]$} & i ：部屋を棈成する矩形面 \\
\hline $\mathrm{h}$ & :慜厷達事 & {$\left[\mathrm{H} / \mathrm{m}^{2 \circ} \mathrm{C}\right]$} & p ：部屋を棈成する全矩形面 \\
\hline $\mathrm{k}$ & : 温度係数 & {$\left[\mathrm{K}^{3}\right]$} & a : 空気 \\
\hline MRT & : 平均故射温度 & {$\left[{ }^{\circ} \mathrm{C}\right]$} & c : 対流 \\
\hline $\mathrm{m}$ & :矩形面の数 & {$[-]$} & $r$ ：篤放射 \\
\hline 0T & : 作用温度 & {$\left[{ }^{\circ} \mathrm{C}\right]$} & s ：顕熱 \\
\hline Q & :単位面稹当り熱交換星 & {$\left[\omega / m^{2}\right]$} & 無次元数 \\
\hline $\mathrm{v}$ & :風速 & {$[\mathrm{m} / \mathrm{s}]$} & $\mathrm{Nu}$ :Nusse1t 数 \\
\hline$\varepsilon$ & : 故射事 & {$[-]$} & $\operatorname{Pr}:$ Prandtle数 \\
\hline & & {$\left[W / \mathbb{m}^{2} \mathbb{K}^{4}\right]$} & \\
\hline
\end{tabular}

量 $Q_{d j-1}\left[\mathrm{~W} / \mathrm{m}^{2}\right]$ は, 次式となる (図一2参照)。

$$
Q_{d j-l}=\varepsilon \sigma k F_{d j-l}\left(t_{d_{j}}-t_{i}\right)
$$

微小面 $d j$ とその面からのぞめるすべての矩形面との間 の直接熱交換量 $Q_{d_{j-p}}\left[\mathrm{~W} / \mathrm{m}^{2}\right]$ は次式で示される。

$$
\begin{aligned}
Q_{d j-p} & =\varepsilon \sigma k \sum_{i=1}^{m} F_{d_{j-l}}\left(t_{d j}-t_{i}\right) \ldots \ldots \ldots \\
& =h_{r}\left(t_{d j} \sum_{i=1}^{m} F_{d_{j-i}}-\sum_{i=1}^{m} F_{d_{j-i}} t_{i}\right)
\end{aligned}
$$


ただし，

$\varepsilon:$ 直方体表面の放射率

$\sigma:$ ステファン・ボルツマンの定数

$=5.67 \times 10^{-8} \mathrm{~W} / \mathrm{m}^{2} \mathrm{~K}^{4}$

$k:$ 温度係数 $\mathrm{K}^{3}$

$F_{d j-l}$ : 直方体の面 $j$ 上の微小面 $d j$ と矩形面 $i$ との間 の形態係数

$t_{d j}:$ 微小面 $d j$ の表面温度 ${ }^{\circ} \mathrm{C}$

$t_{i}:$ 面 $i$ の表面温度

$h_{r}:$ 放射熱伝達率 $\mathrm{W} / \mathrm{m}^{2 \circ} \mathrm{C}$

ここで, $\sum_{i=1}^{m} F_{d j-t}=1$ より

$$
Q_{d j-l}=h_{r}\left(t_{d i}-\sum_{i=1}^{m} F_{d j-i} t_{i}\right)
$$

右辺かっこ内第 2 項は微小面 $d j$ における平均放射温度 $M R T_{d j}\left[{ }^{\circ} \mathrm{C}\right]$ であり, 次式で表される。

$$
M R T_{d j}=\sum_{i=1}^{m} F_{d j-i} t_{i}
$$

直方体の一面 $j$ 全体に対する平均放射温度は, 次のよ うに定義される。

人体モデルとしての直方体の一面 $j$ と矩形面 $i$ との間 の直接熱交換量 $Q_{J-i}\left[\mathrm{~W} / \mathrm{m}^{2}\right]$ は, 次式で表せる。

$$
Q_{j-i}=h_{r}\left(t_{j}-\sum_{i=1}^{m} F_{j-i} t_{i}\right)
$$

ただし，

$t_{j}:$ 面 $j$ の平均表面温度 ${ }^{\circ} \mathrm{C}$

したがって, 面 $j$ に対する平均放射温度 $M R T_{j}\left[{ }^{\circ} \mathrm{C}\right]$ は,

$$
M R T_{j}=\sum_{i=1}^{m} F_{J-i} t_{i} \cdot
$$

$F_{j-i}$ : 直方体の一面 $j$ と矩形面 $i$ との間の形態係数 $Q_{j-i}$ を式（5）を用いて表現すると,

$$
\begin{aligned}
& Q_{j-i}=\int_{A j} Q_{d_{j-i}} d A_{j} / A_{j} \\
& =\int_{A j} h_{r}\left(t_{d j}-\sum_{i=1}^{m} F_{d j-i} t_{i}\right) d A_{j} / A_{j} \\
& =h_{r}\left(\int_{A j} t_{d j} d A_{j} / A_{j}-\int_{A_{j}} \sum_{i=1}^{m} F_{d j-l} t_{i} d A_{j} / A_{j}\right)
\end{aligned}
$$

ここで, $\int_{A_{j}} t_{d j} d A_{j} / A_{j}$ は直方体上の面 $j$ の平均表面温 度 $t_{j}$ を表す。すなわち,

$$
t_{j}=\int_{A_{j}} t_{j} d A_{j} / A_{j}
$$

式（12）を式（11）に代入すると次式が得られる。

$$
Q_{J-i}=h_{r}\left(t_{j}-\sum_{i=1}^{m} \int_{A j} F_{d j-l} d A_{j} t_{i} / A_{j}\right)
$$

ここで, 面と面との間の形態係数 $F_{j-i}$ 之微小面と面と の間の形態係数 $F_{d j-t}$ の関係は次式!)で表せる。

$$
F_{j-i}=\int_{A j} F_{d_{j-i}} d A_{j} / A_{j}
$$

この関係を式（13）に代入すると式（7）となり，
$M R T_{d j}$ と $M R T$ ，との関係は，次のように表される。

$$
h_{r}\left(t_{j}-\int_{A j} \sum_{i=1}^{m} F_{d j-l} t_{i} d A_{j} / A_{j}\right)=h_{r}\left(t_{j}-\sum_{i=1}^{m} F_{j-i} t_{i}\right)
$$

これを変形して, 式 $(6)$ と式 $(8)$ を用いて, 次式を 得る。

$$
M R T_{j}=\int_{A j} M R T_{d j} d \dot{A}_{j} / A j
$$

次に人体モデルとしての直方体全体に対する平均放射温 度と部分平均放射温度との関係を示す。

直方体全体に対する平均放射温度 $\left.M R T{ }^{\circ}{ }^{\circ} \mathrm{C}\right]$ は，

$$
M R T=\sum_{i=1}^{m} F_{R-i} t_{i}
$$

直方体 $R$ と矩形面 $i$ との間の形態係数 $F_{R-i}$ と直方体上 の面 $j$ 之矩形面 $i$ との間の形態係数 $F_{j-i}$ との関係は, 次式で与えられる。

$$
F_{R-i} A_{R}=\sum_{j=1}^{6} F_{J-i} A_{j}
$$

ただし，

$A_{R}:$ 直方体 $R$ の表面積 $\mathrm{m}^{2}$

$A_{j}:$ 直方体 $R$ 上の面 $j$. の面積 $\mathrm{m}^{2}$

$$
\sum_{j=1}^{6} A_{j}=A_{R}
$$

したがって，

$$
F_{R-i}=\sum_{j=1}^{6} F_{j-i} A_{j} / A_{R}
$$

式（20）を式（17）に代入する。

$$
M R T=\sum_{i=1}^{m} \sum_{j=1}^{6}\left(F_{j-i} A_{j} / A_{R}\right) t_{i}
$$

これに式（8）を代入して,

$$
M R T=\sum_{j=1}^{6} M R T_{j} A_{j} / A_{R}
$$

さらに, 式 (16) の関係を代入して, $M R T$ と $M R T_{d s}$ との関係を求めると次式が得られる。

$$
M R T=\sum_{j=1}^{6} \int_{A j} M R T_{d j} d A_{j} / A_{R}
$$

\section{2 部分作用温度}

熱放射環境を体感との関係で表現する場合，平均放射 温度と気温・風速を含んだ作用温度を用いると，体感と 良く対応する ${ }^{16)}$ 。直方体の各面についての作用温度も定 義できる。直方体の 1 面 $j$ の顕熱交換量 $Q_{s J}\left[\mathrm{~W} / \mathrm{m}^{2}\right]$ は次式で表せる。

$$
\begin{aligned}
Q_{s j} & =h_{c j}\left(t_{j}-t_{a}\right)+h_{r}\left(t_{j}-M R T_{j}\right) \\
& =\left(h_{c j}+h_{r}\right)\left(t_{j}-O T_{j}\right) \cdots \cdots \cdots \cdots
\end{aligned}
$$

ただし，

$h_{c j}$ : 面 $j$ での対流熱伝達率 $\mathrm{W} / \mathrm{m}^{2 \circ} \mathrm{C}$

ここで, $O T_{3}\left[{ }^{\circ} \mathrm{C}\right]$ を部分作用温度と呼ふこととし, 次 式で表される。

$$
O T_{j}=\left(h_{c j} t_{a}+h_{r} M R T_{j}\right) /\left(h_{c j}+h_{r}\right)
$$

対流熱伝達率は, 各面ごとに必要であるが, 求めるのが 
困難であるので，ここでは以後全体で一様として取り扱 う。人体の対流熱伝達率は, 様々な值が提案されている が，ここでは，熱放射は直方体を人体モデルとしている ので, 対流についても直方体の值を用いることとする。 直方体・立方体に対する 2 次元流の対流熱伝達率の実験 式 ${ }^{12)}$ は，次式で与えられる。

$$
N u=C P r^{0.35} \operatorname{Re}^{b} \text {...... }
$$

ただし，

直方体: $C=0.264, b=0.66$

立方体 : $C=0.18, b=0.699$

これに，人体モデルとしての直方体・立方体の代表寸法 として, 人体の横幅に当たる, $40 \mathrm{~cm} \cdot 50 \mathrm{~cm}$ を代入して, 対流熱伝達率 $h_{c}\left[\mathrm{~W} / \mathrm{m}^{2 \circ} \mathrm{C}\right]$ の式として次式を得た。

直方体：

$$
h_{c}=12.2 v^{0.66}
$$

立方体：

$$
h_{c}=11.62 v^{0.699}
$$

ただし，

$$
v: \text { 風速 } \mathrm{m} / \mathrm{s}
$$

\section{3 非対称性・不均一性の表現}

次に，非対称性の強さの程度についての表現方法を考 える。Boeke と Wall ${ }^{81} の$ Radiative Asymmetry や Fanger $ら^{9)} の$ Radiation Asymmetry は, 前と後, 右と 左または上と下の背中合わせの 2 方向についてのみの非 対称性の評価しか行えない。また, Boeke と Wall ${ }^{8)}$ の Sensing Cube（微小立体）や中村 ${ }^{2}$ の放射束べクトルは 6 方位に対しての評価は可能であるが，実感としてとら えにくく，空間の点に対しての表現である。ここでは大 きさのある人体を対象として考えるため, 上述の部分平 均放射温度を用いる。人体モデルとしての直方体全体に 対する平均放射温度 $M R T$ は, 部分平均放射温度 $M R T_{j}$ の重み平均である。人体に対する熱放射環境の非対称 性・不均一性は各面の部分平均放射温度相互間の差によ る。そこで, 直方体 6 面の部分平均放射温度のバラツキ
を次式で示される標準偏差 $S D_{M R T}$ で表すこととし，こ れを熱放射不均一度と呼ぶ。

$$
S D_{M R T}=\sqrt{\sum_{j=1}^{6}\left(M R T_{j}-M R T\right) A_{j} / A_{R}}
$$

最終的に, 熱放射環境を平均放射温度 $M R T$ と部分平 均放射温度の標準偏差である熱放射不均一度 $S . D_{M R T}$ を もって表示すれば，人体全体に対する熱放射環境と非対 称性や不均一性が表現できる。その表示法を以下のよう に提案する。

$$
M R T=M R T \pm\left[S D_{M R T}\right]^{\circ} \mathrm{C}
$$

具体的に数字を用いれば,

$$
M R T=28 \pm[5]^{\circ} \mathrm{C}
$$

のように表現する。

\section{3. 実験計画}

\section{1 実験装置および設定条件}

実験は，既報 ${ }^{13), 14)}$ の回流式風洞内で被験者が気流に正 対して椅座し，人体右側または両側に面発熱体を置き非 対称放射熱環境を作り 2 種の実験（実験 $\mathrm{A}$ および $\mathrm{B}$ と呼 ぶ）を行った。実験 Aでは，人体右側 $1.1 \mathrm{~m}$ に面発熱 体の熱放射板 $(2.1 \mathrm{~m} \times 2.1 \mathrm{~m})$ を置き，表一 1 の設定条:

\begin{tabular}{|c|c|c|c|c|c|c|}
\hline 実験記号 & B 1 & B 2 & B 3 & B 4 & B 5 & B 6 \\
\hline 作用温度 & $28^{\circ} \mathrm{C}$ & $28^{\circ} \mathrm{C}$ & $28^{\circ} \mathrm{C}$ & $28^{\circ} \mathrm{C}$ & $28^{\circ} \mathrm{C}$ & $28^{\circ} \mathrm{C}$ \\
\hline 相対湿度 & $50 \pm 5 \%$ & $50 \pm 5 \%$ & $50 \pm 5 \%$ & $50 \pm 5 \%$ & $50 \pm 5 \%$ & $50 \pm 5 \%$ \\
\hline 風 速 & $0.12 \mathrm{~m} / \mathrm{s}$ & $0.12 \mathrm{~m} / \mathrm{s}$ & $0.12 \mathrm{~m} / \mathrm{s}$ & $0.12 \mathrm{~m} / \mathrm{s}$ & $0.12 \mathrm{~m} / \mathrm{s}$ & $0.12 \mathrm{~m} / \mathrm{s}$ \\
\hline 気 温 & $28^{\circ} \mathrm{C}$ & $28^{\circ} \mathrm{C}$ & $25^{\circ} \mathrm{C}$ & $26{ }^{\circ} \mathrm{C}$ & $30.9^{\circ} \mathrm{C}$ & $29^{\circ} \mathrm{C}$ \\
\hline 放射板 右 & $28^{\circ} \mathrm{C}$ & $20^{\circ} \mathrm{C}$ & $42^{\circ} \mathrm{C}$ & $26^{\circ} \mathrm{C}$ & $18.9^{\circ} \mathrm{C}$ & $17.7^{\circ} \mathrm{C}$ \\
\hline 表面温度 左 & $28^{\circ} \mathrm{C}$ & $36^{\circ} \mathrm{C}$ & $42^{\circ} \mathrm{C}$ & $48.7^{\circ} \mathrm{C}$ & $18.9^{\circ} \mathrm{C}$ & $29^{\circ} \mathrm{C}$ \\
\hline 平均放射温度 & $28^{\circ} \mathrm{C}$ & $28^{\circ} \mathrm{C}$ & $30^{\circ} \mathrm{C}$ & $29.3^{\circ} \mathrm{C}$ & $26.6^{\circ} \mathrm{C}$ & $27.4^{\circ} \mathrm{C}$ \\
\hline
\end{tabular}
件とした。実験 Bは，Aと同様に風洞内の被験者位置の 左側 $1 \mathrm{~m}$ には熱放射板（高 $1.6 \mathrm{~m} \times$ 幅 $2 \mathrm{~m}$ ) を, 右側 1

表一1 実験 $\mathrm{A}$ の設定条件

$\begin{array}{llll}\text { 実験記号 } & \text { A } 1 & \text { A } 2 & \text { A } 3\end{array}$

\begin{tabular}{cccc}
\hline 気温 & $27.5{ }^{\circ} \mathrm{C}$ & $27.5{ }^{\circ} \mathrm{C}$ & $27.5{ }^{\circ} \mathrm{C}$ \\
風 速 & $0.18 \mathrm{~m} / \mathrm{s}$ & $0.18 \mathrm{~m} / \mathrm{s}$ & $0.70 \mathrm{~m} / \mathrm{s}$ \\
相対湿度 & $50 \pm 5 \%$ & $50 \pm 5 \%$ & $50 \pm 5 \%$ \\
熱放射 & \multicolumn{1}{c}{ 平均放射温度 } & $30{ }^{\circ} \mathrm{C}$ \\
& 右面平均放射温度 & $40{ }^{\circ} \mathrm{C}$ \\
\hline
\end{tabular}

表一2 実験 B の設定条件 


\begin{tabular}{|c|c|c|c|}
\hline 被験者記号 & $\mathrm{A}$ & \multicolumn{2}{|l|}{$\mathrm{Y}$} \\
\hline 実験時年齢 & 24 & 24 & \\
\hline 身 長 & $171.0 \mathrm{~cm}$ & $166.2 \mathrm{~cm}$ & 164 \\
\hline 体 重 & $67.0 \mathrm{~kg}$ & $61.5 \mathrm{~kg}$ & $g$ \\
\hline 体表面積 & $1.74 \mathrm{~m}^{2}$ & $1.64 \mathrm{~m}^{2}$ & \\
\hline 出 身 地 & 和歌山県 & 山形県 & \\
\hline 表一4 & 与皮成 & 用重み係数 & \\
\hline 部 位 & 全体 & 右側 & 左側 \\
\hline 前 額 & 0.07 & 0.07 & 0.07 \\
\hline 三角筋 ，右 & 0.035 & 0.07 & \\
\hline 三角筋 左 & 0.035 & & 0.07 \\
\hline 前膊外 右 & 0.035 & 0.07 & \\
\hline 前膊外 左 & 0.035 & & 0.07 \\
\hline 手 背 右 & 0.025 & 0.05 & \\
\hline 手 背 左 & 0.025 & & 0.05 \\
\hline 腹 部 右 & 0.0875 & 0.175 & \\
\hline 腹 部 左 & 0.0875 & & 0.175 \\
\hline 腸骨節＼cjkstart右 & 0.0875 & 0.175 & \\
\hline 腸骨節 左 & 0.0875 & & 0.175 \\
\hline 大腿前 右 & 0.095 & 0.19 & \\
\hline 大腿前 左 & 0.095 & & 0.19 \\
\hline 下腿前＼cjkstart右 & 0.065 & 0.13 & \\
\hline 下腿前 & 0.065 & , & 0.13 \\
\hline 足 背 右 & 0.035 & 0.07 & \\
\hline 足 背 左 & 0.035 & & 0.07 \\
\hline
\end{tabular}

$\mathrm{m}$ には，冷放射源と熱放射源のいずれにもなる放射板

（高 $1.7 \mathrm{~m} \times$ 偪 $2.4 \mathrm{~m}$ ) を置き, 表一2の設定条件とした。 人体側条件としては, ブリーフのみで, 暴露時間中椅座 安静を保った。実験は, 気温 $28^{\circ} \mathrm{C}$ (=平均放射温度), 相対湿度 $50 \pm 10 \%$ ，静穏気流の前室で 30 分滞在後，実 験 Aでは 65 分, 実験 Bでは 90 分間設定条件に暴露した。 被験者は, 表一 3 に示す健康な青年男子を用いた。なお, 被験者には報酬を支払っだ。

\section{2 測定項目}

環境条件として,気温と湿度はアスマン乾湿球湿度計, 気流は熱線風速計, 熱放射は各放射板表面温度 12 点と

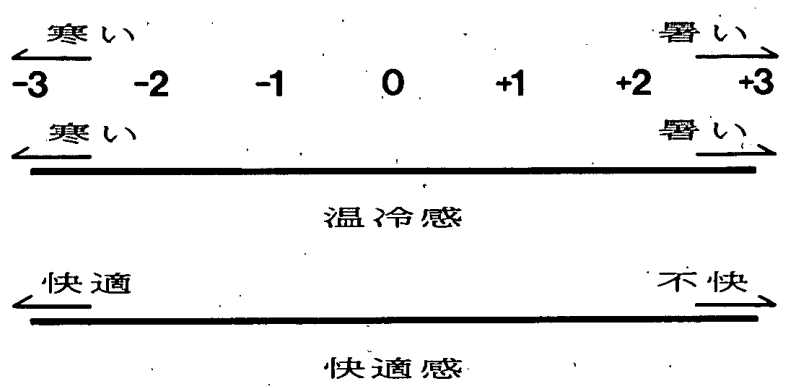

図一3 温冷感・快適感評定尺度

表一5 実験 Aにおける各熱放射環境指標の計算結果

\begin{tabular}{|c|c|c|c|c|}
\hline \multicolumn{2}{|c|}{ 実験記号 } & A 1 & A 2 & A 3 \\
\hline \multicolumn{5}{|c|}{ 平均放射温度 } \\
\hline 全体 & & $30.9^{\circ} \mathrm{C}$ & $30.4^{\circ} \mathrm{C}$ & $29.6^{\circ} \mathrm{C}$ \\
\hline \multirow[t]{2}{*}{ 部分 } & 右 & $39.8^{\circ} \mathrm{C}$ & $39.4^{\circ} \mathrm{C}$ & $37.4^{\circ} \mathrm{C}$ \\
\hline & 左 & $28.0^{\circ} \mathrm{C}$ & $27.4^{\circ} \mathrm{C}$ & $27.0^{\circ} \mathrm{C}$ \\
\hline \multicolumn{5}{|c|}{ 作用温度 } \\
\hline 全体 & & $29.7^{\circ} \mathrm{C}$ & $29.2^{\circ} \mathrm{C}$ & $28.0^{\circ} \mathrm{C}$ \\
\hline \multirow[t]{2}{*}{ 部分 } & 右 & $35.1^{\circ} \mathrm{C}$ & $34.6^{\circ} \mathrm{C}$ & $29.6^{\circ} \mathrm{C}$ \\
\hline & 左 & $28.0^{\circ} \mathrm{C}$ & $27.4^{\circ} \mathrm{C}$ & $27.0^{\circ} \mathrm{C}$ \\
\hline
\end{tabular}

室内各表面温度を $0.3 \mathrm{~mm} \phi \mathrm{T}$ 熱電対で測定し，グロー ブ温度計および放射収支計で監視した。人体反応として は, Hardy-DuBois ${ }^{15)}$ の 7 点と三角筋について左右各部 位の皮膚温を $0.2 \mathrm{~mm} \phi \mathrm{T}$ 熱電対で測定した。なお，実 験 Bでは手足の指についても皮膚温を測定した。平均皮 膚温は, 表一 4 に示す重み係数を用いて, 人体右側・左 側・全体について計算した。体重減少量は, 人体用台科

（感度 $1 \mathrm{~g}$ ）で計測した。心理的反応は, 図一3に示す 評定尺度を用いて全身温冷感と快適感を測定した。実験 Aでは，数値尺度を用いて皮膚温测定部位について，部 位温冷感を測定した。 


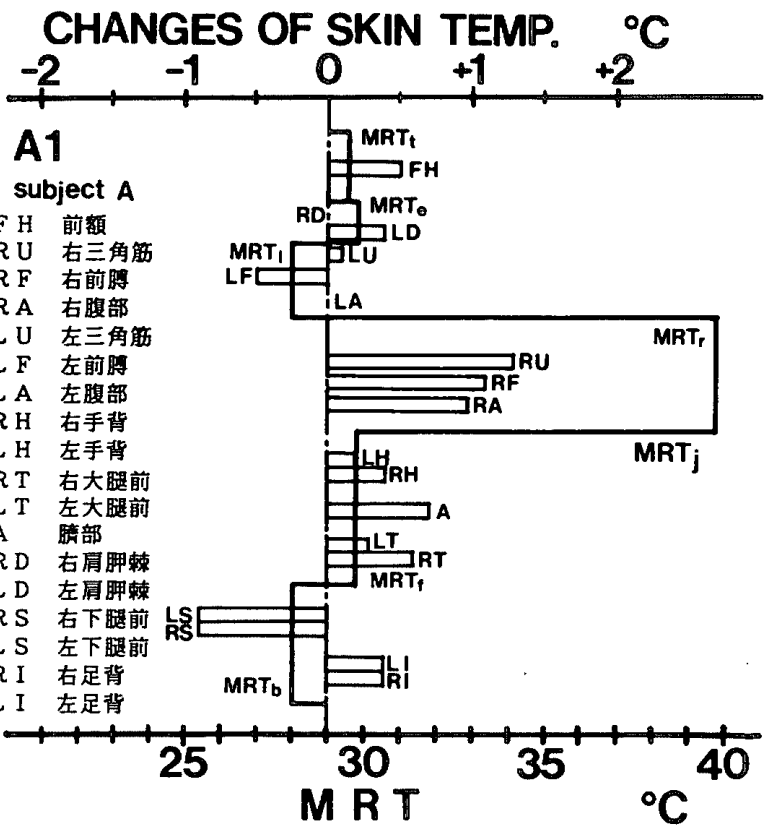

図一4 部分平均放射温度と部位皮噳温変化との関係（実験 A 1)

THERMAL SENSATION VOTE
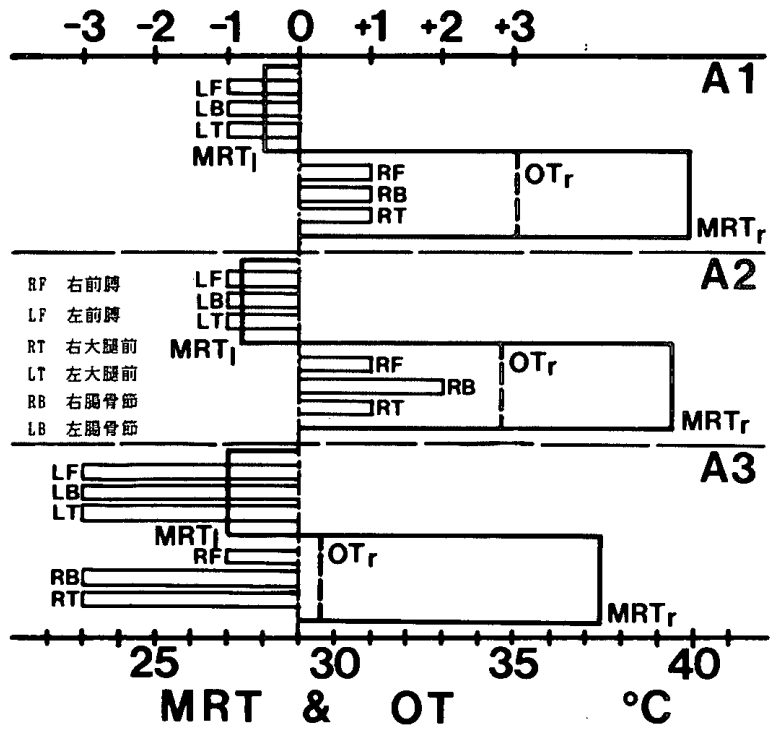

図一5 部分平均放射温度・部分作用温度と部位温冷感との関係 (実験A)

\section{4. 実験結果と考察}

4.1 実験 A

1）表一5に暴露後 65 分における環境条件と, 上述の 平均放射温度 ・作用温度の計算結果を示す。部分平均放 射温度は各実験とも左面と右面との差は $10^{\circ} \mathrm{C}$ 以上と なっている。熱放射不均一度も大きい。実験条件 A 3 で は風速が速いため, 作用温度は他の実験条件に比べて気 温に近くなり, 部分作用温度の左右差も $2.6^{\circ} \mathrm{C}$ と他条 件の $7^{\circ} \mathrm{C}$ に比較してかなり小さくなっている。

2）熱放射の表現と人体の生理反忘としての皮膚温との 関係を検討する。これにあたって，皮膚温の絶対的な值 は部位による差が存在するので, 暴露 5 分前の前室での 皮膚温を基準として暴露 65 分後の皮厗温との差をもっ
表一6 各条件ごとの熱放射不均一度，実験 $\mathrm{B}$ の被験者 $\mathrm{M}$ の場合 実験記号 平均放射温度 熱放射不均一度

\begin{tabular}{lll} 
B 1 & $28.2^{\circ} \mathrm{C}$ & $0.1^{\circ} \mathrm{C}$ \\
B 2 & $28.4^{\circ} \mathrm{C}$ & $3.5^{\circ} \mathrm{C}$ \\
B 3 & $30.7^{\circ} \mathrm{C}$ & $5.1^{\circ} \mathrm{C}$ \\
B 4 & $30.6{ }^{\circ} \mathrm{C}$ & $5.7^{\circ} \mathrm{C}$ \\
B 5 & $26.2^{\circ} \mathrm{C}$ & $3.3^{\circ} \mathrm{C}$ \\
B 6 & $26.8^{\circ} \mathrm{C}$ & $2.8^{\circ} \mathrm{C}$ \\
\hline
\end{tabular}

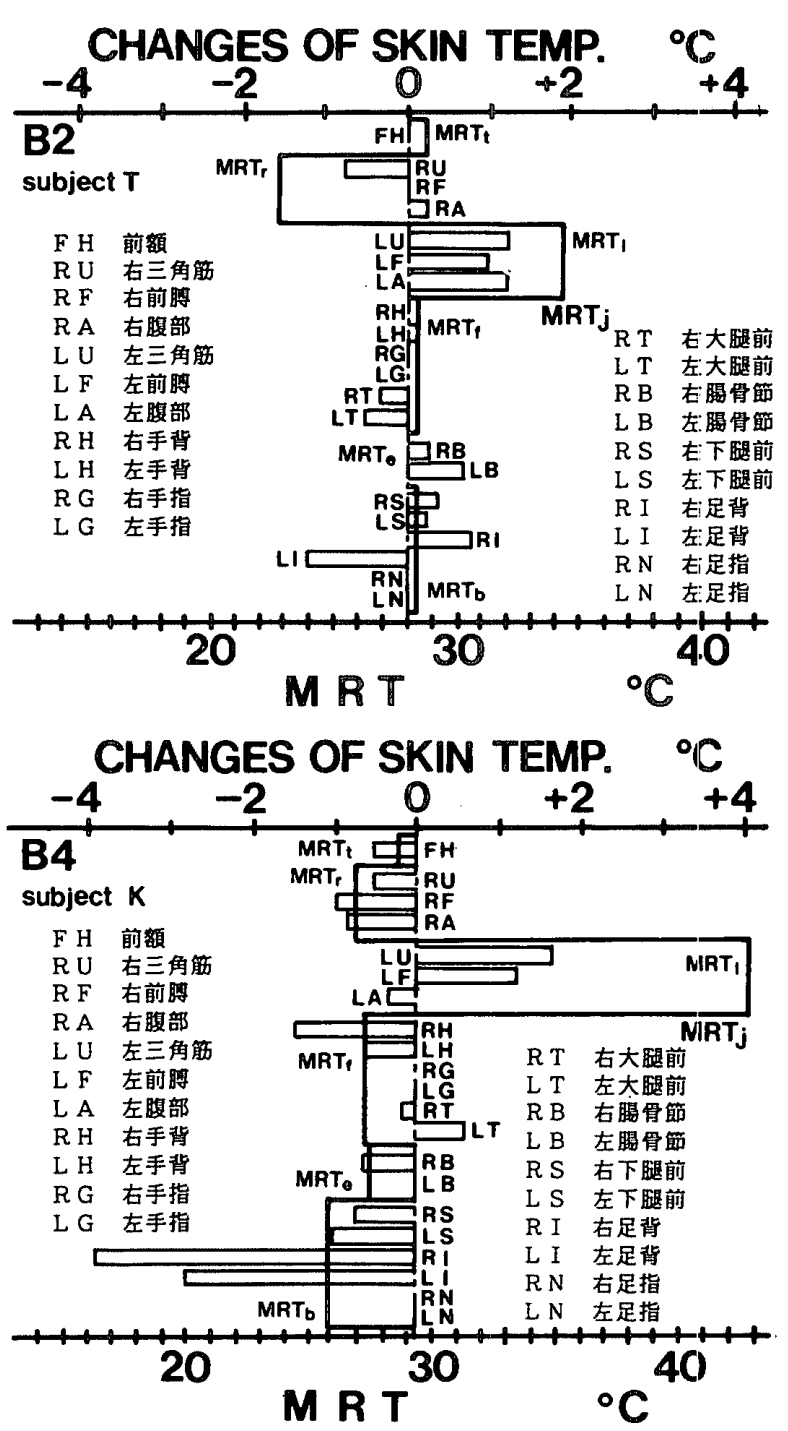

図一6 部分平均放射温度と部位皮膚温変化との関係（実験 B )

て検討する。図一4に，この70分間の皮膚温変化と部 分平均放射温度との関係を実験条件 A1 を例に示す。三 角筋 - 前膊外 - 腹部に皮膚温変化の左右差が大きく現 れ，部分平均放射温度と良く対応していると考えられる。 3）部位温冷感と部分平均放射温度 - 部分作用温度との 関係を検討する。ここでは，左右差のみに着目する。図 -5 に, 部位温冷感亡部分平均放射温度 $\cdot$ 部分作用温度 


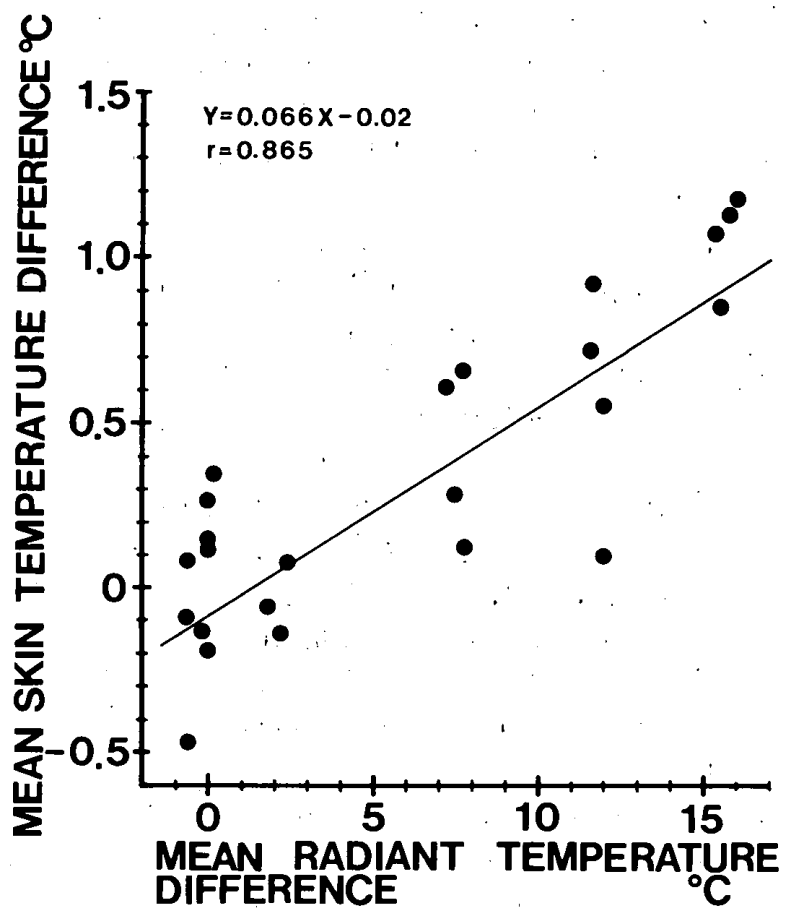

図一7，左右の平均放射温度差と左右の平均皮成温差との関係 (実験 B)

との関係を示す。条件 A 1 およびA2 では, 部分平均放 射温度でも左右差の表現は可能であるが, 風速の速い A 3 条件では, 体感との関係は部分作用温度で行う必要 があることを示している。

\section{2 実験 B}

1）表一6に暴露後 90 分における熱放射不均一度の計 算結果を被験者 $\mathrm{M}$ を例に示す。概して左石差の大きい 平均放射温度を設定した場合は，不均一度は大きくなる が，必ずしも左右差のみには依存しない。これは，人体 左右の面からの熱放射は直方体の左右面にのみ照射され るのではなく, 他の面にも当然照射される。したがって, 1 面の壁面のみが強い不均一性を持つ環境で熱放射不均 一度は大きくなり,良く実態を表現していると考えられ， 人体全体の熱放射の非対称性や不均一性を表現するのに 適した方法である。

2）実験 Aの場合と同様に, 部分平均放射温度と暴露直 前の前室での皮膚温と暴露 90 分後の皮膚温との差の関 係を検討する。図一6に 90 分間の皮膚温変化と部分平 均放射温度との関係の例を示す。左右に非対称性か強い 場合は, 三角筋の皮膚温に影響が現れ，左に温度の高い 放射源のある場合は, 左側三角筋・前膊 ·大腿前の皮㲊 温が $0.5^{\circ} \mathrm{C}$ から $1.5^{\circ} \mathrm{C}$ の上昇を示している。部分平均 放射温度と良く対応している。

3）立方体の左右の面に対する部分作用温度の差と人体 の左右の平均皮膚温差との関係を図一7に示す。両者の 間に強い相関がみられる。部分作用温度によって非対称 な熱放射環境を表現することは妥当であると考えられ る。

\section{5. 結 論}

非対称または不均一な熱放射環境を表現するために， 人体を単純な立体である直方体（立位を想定）または立 方体（椅座位を想定）としてモデル化し，その各面にお ける平均放射温度を部分平均放射温度として提案した。 体感指標としての各面に対する, 部分作用温度も定義し た。そして，人体局所における微小面放射温度と人体モ デルとしての直方体・立方体全体に対する平均放射温度 との関係を定式化した。また，人体全体に対する熱放射 の非対称性・不均一性を表現するための指標として, 各 面の部分平均放射温度の標準偏差にようて表す熱放射不 均一度を提案した。これらの指標の有効性を検証するた め, 左右非対称な熱放射環境に裸体椅座人体を暴露し, 生理反応としての皮膚温と心理反応としての温冷感・部 位温冷感を測定する実験を行った。その結果, 気流条件 が静皧気流の場合は部分平均放射温度と, 気流が 0.7 $\mathrm{m} / \mathrm{s}$ の場合は部分作用温度と, それに対応する部位の皮 虞温変化・部位温冷感と良く対応した。熱放射不均一度 も熱放射の非対称性・不均一性を有効に表現した。した がって, 本研究で提案した指標の有効性が検証されたと 考えられる。

\section{謝 辞}

本研究を行うにあたり，実験に多大なるご協力を頂い た奈良女子大学助教授磯田憲生（当時東京工業大学助 手), 大林組山口賢次郎（当時東京工業大学大学院学生） の両氏および実験に参加頂いた被験者の方々に心から感 謝の意を表します。

\section{既発表文献}

i）小林陽太郎, 堀越哲美, 磯田憲生, 山口賢次郎：非対称 ふく射熱源加の熱ふく射の人体影響, 日本生気象学会 雑誌 No. 13, p. 16, 1976.

ii）堀越哲美, 小林陽太郎：室内における非対称ふく射熱環 境の人体影響の表現方法について一人体の一部分に対す る平均了く射温度と実験一, 日本建築学会大会学術講演 梗概集 (北海道), pp. 575 -576, 1978.

iii）蔵澄美仁, 小林陽太郎, 堀越哲美, 土川忠浩, 平山慶太 郎：不均一熱放射環境の人体影響について一作用温度一 定の場合一, 日本建築学会大会学術講演梗概集 (関東), pp. 915 916, 1984.

\section{引用文献}

1) Horikoshi, T. \& Kobayashi, Y. : Configuration factors between a rectangular solid as a model of the human body and rectangular planes, for evaluation of the influence of thermal radiation on the human body. I. Calculation of configuration factors for the rectangular solids, Transac. tions of A. I. J. No. 253, pp. 91 102, 1977

2）中村泰人：建築都市空間内の人体に対する熱放射場の表 現方法について, 日本建築学会計画系諭文報告集, No. 376, pp. $29 \sim 35,1987$ 
3) Vernon, H.M. : The measurement, in relation to human comfort, of the radiation produced by various heating systems, Proceedings of Institution of Heating and Ventilating Engineers 31, pp. 160 227, 1932

4) Korsgaard, V. : Necessity of using a directional mean radiant temperature to describe the thermal condition in rooms, Heating, Piping \& Air Conditioning 21, pp. 117 $-120,1949$

5) Emmerson, W.E. : Don't sit near the window!, ASHRAE Journal 16(6), pp. 53 56, 1974

6) McIntyer, D. A. : Radiation Draughts, Building Services Engineer 43 (October), pp. 136 139, 1975

7) Mundt, F.E. : Raktad operativ temperature. Institution for uppvarmingsoch ventilationteknik KTH, Stockholm, pp. 120 122, 1976

8) Boeke, W. \& Wall, L. : Radiative exchange factors in rectangular spaces for the determination of mean radiant temperature, Building Services Engineer 43 (March), pp. 244 253, 1976

9) Fanger, P. O., Banhidi, I., Olesen, B. W. \& Langkilde, G. : Comfort limits for heated ceilings, ASHRAE Transactions $86(2)$, pp. 141 156, 1980

10) Horikoshi, T. \& Kobayashi, Y. : Configuration factors between a rectangular solid as a model of the human body and rectangular planes, for evaluation of the influence of thermal radiation on the human body. II. Characteristics of configuration factors for the rectangular solids, Transactions of A.I. J. No. 267, pp.91 101, 1978

11) Siegel, R. \& Howell, J. R. : "Thermal radiation heat transfer", McGraw-Hill, 1972

12) Kutateladze, S. S. \& Borishanskii, V. M. : "A concise encyclopedia of heat transfer" (translated by Arthur, J.B. ), Pergamion Press, 1966

13）磯田憲生, 堀越哲美, 小林陽太郎：回流式風洞 No.2の 概要とその性能について, 日本建築学会大会学葕講演梗 概集 (関東)，pp. 359 360，1975

14）堀越哲美, 小林陽太郎, 土川忠浩, 福島重治：佟正湿り 作用温度 - 温熱風速場 - 有効放射場および娍効湿度場に よる温熱環境条件の人体影響表現方法の検討，日本建築 学会計画系論文報告集, No. 380, pp. 12 23, 1937

15) Hardy, J.D. \& DuBois, E. F. : The technic of measuring radiation and convection, Journal of Nutrition 15 , pp. $461 \sim 475,1938$

16) Winslow, C. E. A., Herrington, L. P. \& Gagge, A. P. :The relative influence of radiation and convection upon the temperature regulation of the clothed body, American Journal of Physiology 124( 1 ), pp. 51 61, 1938

(1990 年 1 月 10 日原稿受理, 1990 年 5 月 8 日採用決定) 